Article

\title{
Provenance analysis and structural study of the Cycladic Blueschist Unit rocks from Iraklia island: from the Paleozoic basement unroofing to the Cenozoic exhumation.
}

\author{
Sofia Laskari 1,**, Konstantinos Soukis ${ }^{1}$, Stylianos Lozios ${ }^{1}$, Daniel F. Stockli ${ }^{2}$, Eirini M. Poulaki ${ }^{2}$, Christina Stou- \\ raiti ${ }^{1}$ \\ 1 Faculty of Geology and Geoenvironment, National and Kapodistrian University of Athens, Greece. \\ 2 Department of Geological Sciences, Jackson School of Geosciences, University of Texas at Austin, USA. \\ * Correspondence: slaskari@geol.uoa.gr; Tel.: (+306971930069; S.L.)
}

\begin{abstract}
Detailed mapping and structural observations on the Cycladic Blueschist Unit (CBU) of Iraklia island integrated by detrital zircon (DZ) U-Pb ages elucidate the Mesozoic pre-subduction evolution and the Cenozoic orogenic events. Field data reveal that the Iraklia tectonostratigraphy includes a heterogeneous Lower Schist Unit juxtaposed against a Variegated Marble Unit and an overlying Upper Schist Unit. The contact is an extensional ductile-to-brittle-ductile, top-to-N shear zone, associated with the Oligo-Miocene exhumation. The DZ spectrum of the Lower Schist Unit characterized by Gondwanan/peri-Gondwanan provenance signatures points to Late Triassic maximum depositional ages (MDAs). A quartz-rich schist layer yielded Precambrian DZ ages exclusively, considered part of the pre-Variscan metasedimentary Cycladic Basement, equivalent to those observed on Ios island. A significant change occurred during the deposition of the Upper Schist Unit, revealing Late Cretaceous MDAs and a high amount of Late Paleozoic DZ ages, attesting to more internal Pelagonian source areas. The imprint of Paleotethyan vs. Neotethyan geodynamic events is revealed in the DZ U-Pb ages record. The Triassic DZ input demonstrates eroded volcanic material related to the final Paleotethys closure and the Pindos/CBU rift basin opening. Late Cretaceous metamorphic/magmatic zircons and $\sim 48-56$ Ma zircon rims constrain the onset of subduction and high-pressure metamorphism.
\end{abstract}

Keywords: Cycladic Blueschist Unit; detrital zircon U-Pb dating; central Cyclades; Provenance

\section{Introduction}

In most cases, poly-deformed and poly-metamorphosed high-grade rocks have lost their fossil record and stratigraphic frame, necessary for local and regional correlations. The lack of a stratigraphic frame hinders the study of subduction and exhumation processes and how these affect the primary structures and the resulting tectonostratigraphy.

The recognition of Metamorphic Core Complexes (MCCs) [1] made the Attic-Cycladic Crystalline Complex (ACCC) the subject for several studies, primarily focused on the structural and metamorphic evolution of the overlying Permo-Mesozoic Cycladic Blueschist Unit (CBU) and the underlying Carboniferous Cycladic Basement (CB). These studies have offered insights into the subduction zone processes and back-arc extension and MCC-formation processes [2,3,4,5,6,7,8,9,10,11,12,13,14,15]. However, many things are still not fully understood. One of them is if and how the transition from Paleotethys subduction cycle to Neotethys opening is imprinted into the CBU rock record.

Iraklia Island holds a critical position between Ios and Naxos (Fig.1), two islands where pre-Alpine CB and the CBU rocks constitute the footwall of MCCs exhumed by the Paros - Naxos low-angle fault. Although previous studies [16,17] reported that Iraklia comprises CBU rocks mainly similar to those of Naxos and Ios, [18] suggested the existence of pre-alpine basement rocks. However, there is no detailed work regarding a) the tectonostratigraphy of Iraklia, b) how the stratigraphy was affected by the Paleotethyan 
and Neotethyan cycles, and c) the stratigraphic/metamorphic correlations with the Ios and Naxos MCCs.

Detrital zircon (DZ) studies in the ACCC have provided fundamental insights regarding the Maximum Depositional Ages (MDAs) and provenance of the CBU and CB rocks. These studies also shed light on the CBU stratigraphy and the pre-Eocene subduction paleogeographic organization $[19,20,21,22,23,24,25,26,14,15]$.

This study combines detailed mapping, structural observations, and DZ U-Pb geochronology to refine a) the tectonostratigraphy of Iraklia CBU rocks, b) to establish tectonostratigraphic and metamorphic correlations with the neighboring Ios and Naxos, and c) to reconstruct the pre-subduction history of Iraklia, as part of the regional Paleotethyan to Neotethyan evolution.

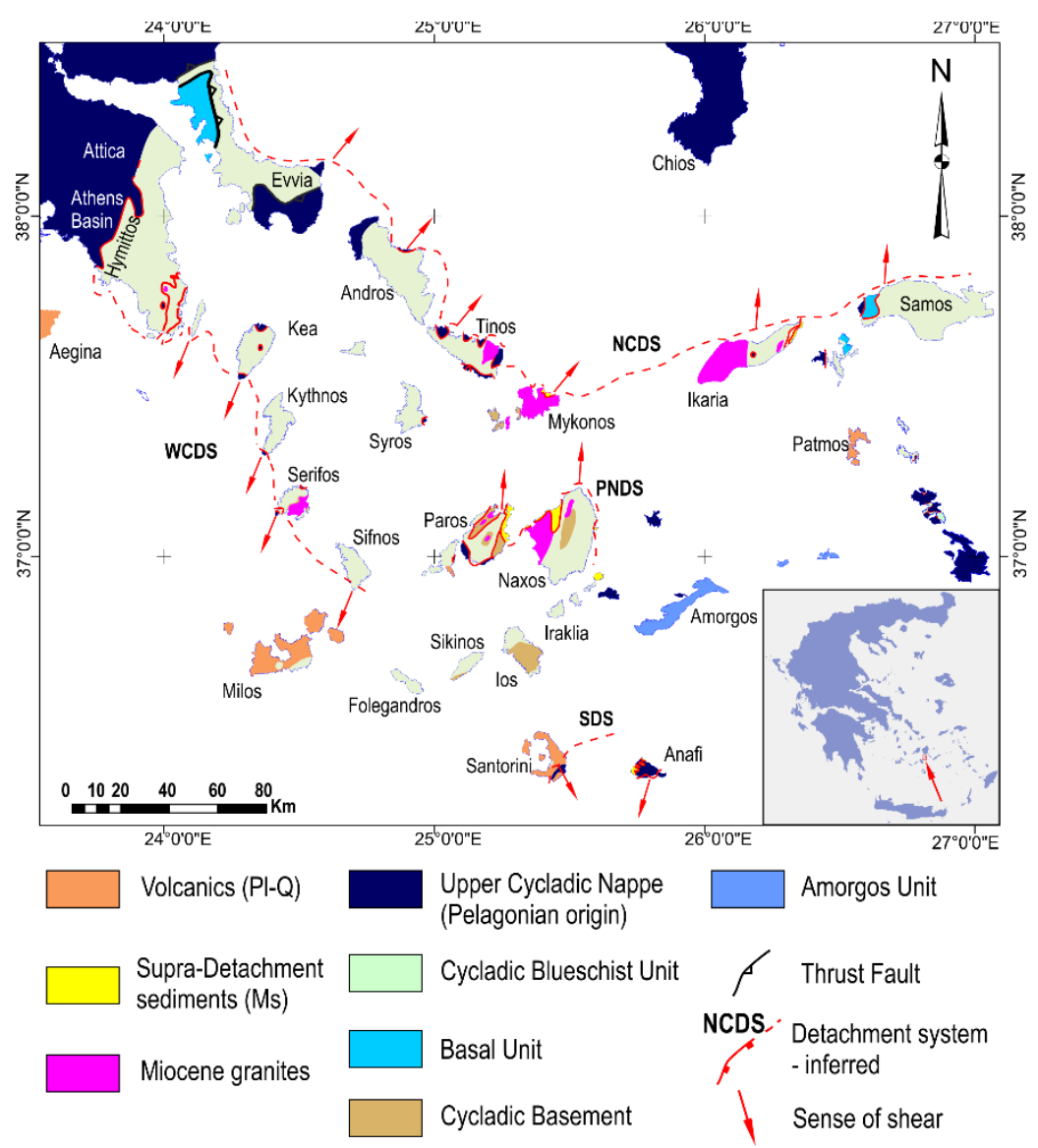

Figure 1: Schematic map (a) of major structures in Greece and detailed map of the ACCC (b) illustrating the main units, the major structures, and the location of Iraklia Island (inlet). North Cycladic Detachment System (NCDS), Paros-Naxos Detachment System (PNDS) West Cycladic Detachment System (WCDS), and Santorini Detachment System (SDS) compiled from $[26,3,27,28,5,7,8,29,30,13]$.

\section{Geological Setting}

The ACCC represents the deepest exhumed parts of the Hellenides due to ? Late Oligocene-Miocene back-arc extension resulted from accelerated slab roll-back of the subducting plate $[31,6,8]$. The tectonostratigraphy of the ACCC comprises the dominant CBU and the underlying pre-alpine $\mathrm{CB}$, which constitute the exhumed lower plate. The upper plate comprises the Upper Cycladic Nappe and the late Miocene supra-detachment sediments, tectonically overlying the CBU $[32,33,18,27,6,8,34]$.

The CBU includes a Permo-Mesozoic sequence of marble, metasediments, and metavolcanic rocks metamorphosed under eclogite to blueschist facies in the Eocene, which are best preserved today on Syros, Sifnos, and Tinos islands $[35,36,37,38,39]$. The 
CBU rocks have experienced an early HP history during the Eocene ( 45-53Ma) [40,41, 42]. Recently, a prolonged Early Eocene to Oligocene HP metamorphic event has been proposed $[43,44]$. During the Oligo-Miocene, these rocks have been reworked in higher temperatures from greenschists facies to amphibolite facies and partial melting conditions (e.g., Naxos, Paros, Ikaria and Mykonos [35,45,46,47,48,49,50,51].

A two-stage exhumation has been documented for the rocks of CBU. First, an earlier Eocene-Oligocene syn-orogenic exhumation stage occurred within the subduction zone. The second stage included a ?Late Oligocene - Miocene post-orogenic exhumation, forming the MCCs via the low-angle detachment systems [52,53,54,6,7,8,55,56,34,57]. The major detachment systems that have been identified juxtaposing the CBU against the Upper Cycladic Nappe are: i) the North Cycladic Detachment System (Andros, Tinos, Mykonos, Ikaria) and the Paros-Naxos Detachment System (Paros, Naxos, Ios) with top-to-the N-NE kinematics, and ii) the West Cycladic Detachment System (Attica, Kea, Kythnos, Serifos) and the South Cycladic Shear Zone and the Santorini Detachment (Ios, Santorini) with top-to-the S-SW kinematics, supporting the scenario of a symmetric pattern of extension in the Aegean $[1,58,6,7,8,29,59,9,10,60,13,61,62]$. Emplacement of syn-tectonic Miocene Iand S-type granitic intrusions due to migration of the magmatic arc marked the latest activity of these detachment systems $[63,27,5,64,56]$.

The CB is mainly exposed on the islands of Paros, Naxos, Ios, Sikinos and comprises Variscan granitoids and orthogneisses that intruded into a Late Proterozoic - Early Paleozoic sequence related to the closure of the Paleotethys $[35,65,66,32,67,68,69,70,20,71,14]$. The contact between $\mathrm{CB} / \mathrm{CBU}$ is considered either a low-angle fault, ductile shear zone $[72,73,74,75]$, or thrust [54]. Recent detrital zircon U-Pb studies have documented continuous sedimentation of the CBU from the late Permian to late Cretaceous, on top of the CB with no hiatus $[19,76,23,25]$. Consequently, a parautochthonous nature for the contact between CB and CBU is suggested [15]. Detrital zircon dating throughout the Cyclades revealed a Godwanan provenance of the $\mathrm{CB}$ and CBU rocks [20] that is changed by the time the CBU rocks entered the subduction zone, as significant input from the Internal Hellenides is documented [25,71,14,15].

Structurally above the CBU lies the Upper Cycladic Nappe. It is a diverse group of low-grade to amphibolite-facies Permian to Mesozoic metasedimentary rocks, granitic orthogneiss, and metamorphosed ophiolitic rocks (the latter locally known as Upper Unit). The Upper Cycladic Nappe is intruded in a few places by late Cretaceous granitoids, and it is correlated to the Pelagonian domain of continental Greece $[35,32,77,66,78,79,63,4,80,28,11,34]$.

The geology of Iraklia island was first studied by the Greek Geological survey [16], which led to the 1:50000 scale geological map for Iraklia and Schinoussa islands. These workers reported the existence of a (?)Triassic marble sequence, overlying schist and marble alternations, which they assigned to CBU. A structural and paleo-piezometric analysis has been conducted, suggesting a four-stage deformation that includes an earlier D1 related to the Eocene metamorphism, D2 shearing with top-to-the-north kinematics [17]. The syn-tectonic temperature conditions are constrained at 400-450 $\mathrm{C}$ and differential stress approximately at 29-62 MPa. In contrast, D3 and D4 deformation phases were attributed to E-W shortening, which resulted in isoclinal folding and reverse faulting. The same authors reported blueschists facies assemblages from the southwestern part of the island, suggesting that the main deformation phase occurred within the stability field of glaucophane.

The lithostratigraphy, structural evolution, and $\mathrm{U}-\mathrm{Pb}$ detrital zircon analysis of Iraklia will be presented and discussed in the following paragraphs. Furthermore, the tectonostratigraphic relationships with the neighboring islands of Naxos and Ios will also be highlighted.

\section{Geology of Iraklia}




\subsection{Lithostratigraphy}

Field observations revealed that the lithostratigraphic column of CBU on Iraklia island could be divided into two parts, juxtaposed through a ductile to brittle-ductile shear zone. The lower part includes the Lower Schist Unit, which is exposed mainly at the central and southern part of the island, but also a limited outcrop is observed in the northeastern region. The Lower Schist Unit is lithologically quite heterogeneous. It includes light brown quartz-mica schists interlayered locally with isoclinally folded light gray to dark blue marble, lenses of paragneiss, and quartz-rich schist. The upper part of the lithostratigraphic column includes the Upper Schist Unit and the Variegated Marble Unit. The Upper Schist Unit is light green to light brown intensively quartz-chlorite mica-schist intercalated with thin marble layers (Fig.2a). The thick Variegated Marble Unit, interposed between the Lower and Upper Schist Units, is a well-foliated marble sequence, often dolomitic and it is outcropping on most of Iraklia. The Upper Schist Unit shows evidence for a transition with the underlying Variegated Marble Unit, and the two units are folded together with large-scale N-S isoclinal folds.

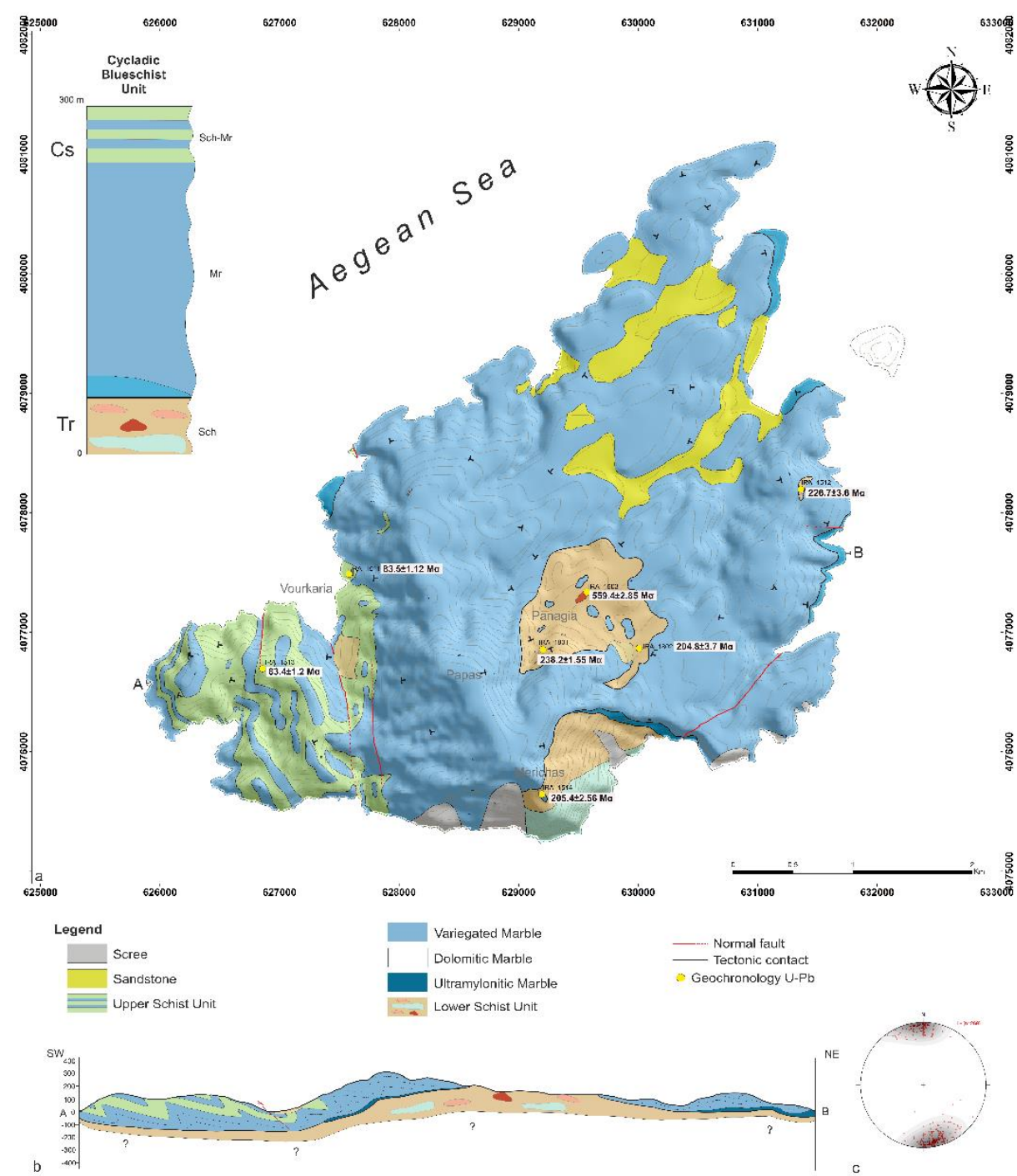

Figure 2: (a). Detailed geological map of Iraklia Island and cross-section (b), samples location collected for U-Pb detrital zircon dating (yellow circles), and (c) Stereoplot (lower hemisphere equal-area projection) of stretching lineation (Ln).

Contrary, the Lower Schist Unit is juxtaposed against the Variegated Marble through a ductile to brittle-ductile shear zone marked by the presence of an ultramylonitic marble 
at its base (Fig.2b, 3). This ultramylonitic marble is exposed only in a few places along the coast. At the structural top of the Variegated Marble Unit, minor meta-bauxite occurrences are observed at northwestern Iraklia [this study, 81,17].
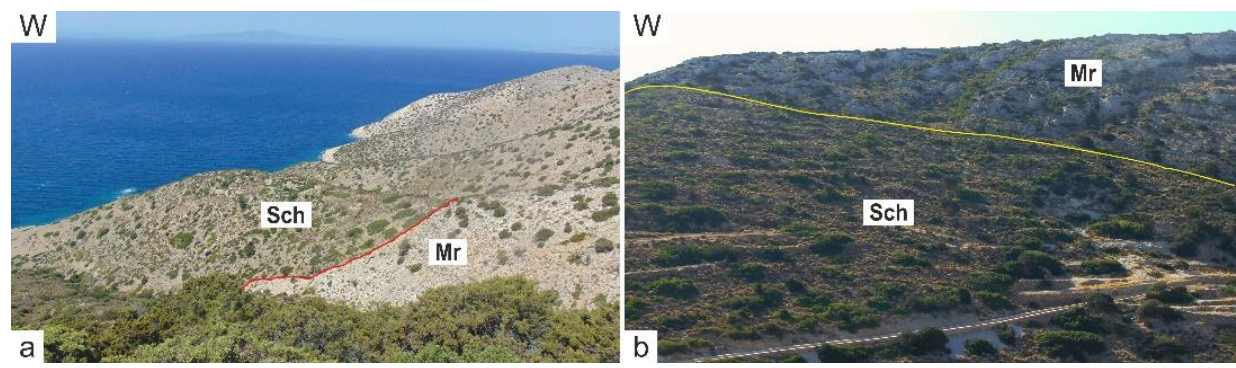

Figure 3: a. View of the uppermost quartz-chlorite mica-schist overlying the marbles (red line) in the SW part of the island $\left(36^{\circ} 50^{\prime} 11^{\prime \prime} N, 25^{\circ} 26^{\prime} 14^{\prime \prime} E\right)$, (b). Main tectonic contact (yellow line) between the lowermost quartz-mica schists and the variegated marble sequence from the central part of the island $\left(36^{\circ} 49^{\prime} 57^{\prime \prime} N, 25^{\circ} 27^{\prime} 2^{\prime \prime} E\right)$.

\subsection{Structures}

Structural analysis on the CBU rocks on Iraklia revealed a three-stage deformation event (D1-D3), evolving from ductile to brittle conditions.

\subsection{D1 Syn-Blueschist facies structures}

The oldest D1 structure observed in thin sections is a relic foliation S1 formed under blueschist-facies conditions, as revealed by the presence of glaucophane grains. Glaucophane is preserved as inclusions in K-feldspar porphyroblasts, syn-tectonic to the greenschist facies assemblages. These inclusions usually form an internal foliation, subparallel to the main external S2 foliation (Fig. 4a, b). It should be noted that the blueschist minerals are observed mainly in the Upper Schist Unit from southwest Iraklia.
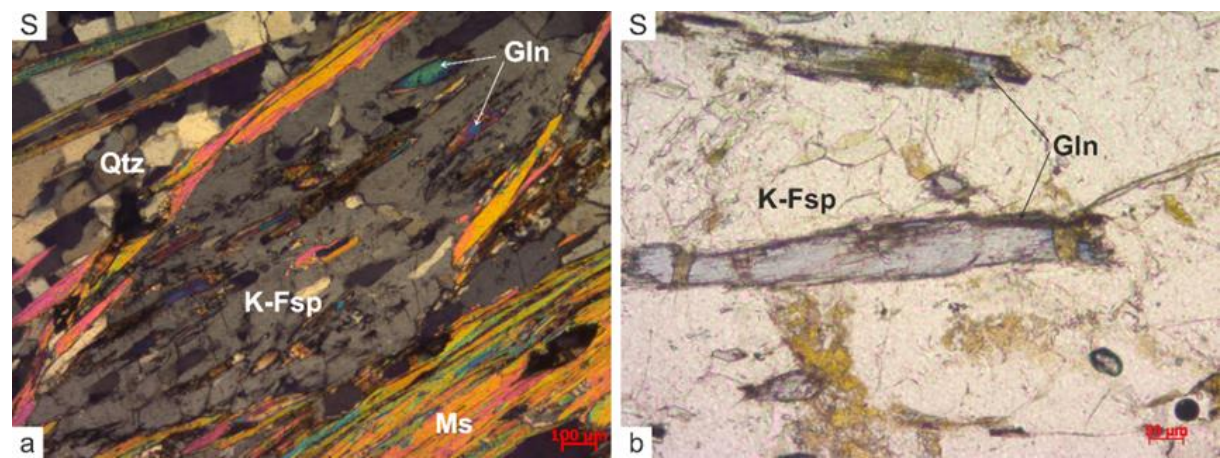

Figure 4: Microphotographs of glaucophane from the Upper Schist Unit, of SW Iraklia. (a). K-Feldspar porphyroblast with glaucophane inclusions (crossed polars), and (b). Elongate glaucophane grains boudinaged during the main D2 deformation stage.

\subsection{D2 Ductile to brittle deformation}

The main D2 syn-metamorphic deformation stage is associated with the development of a dominant penetrative medium to fine-grained proto- to meso-mylonitic foliation (S2) that dips shallowly towards the east and west. An N-S stretching lineation (L2) is formed on the S2 foliation planes, defined by the aligned and stretched calcite-quartzmicas aggregates. In thin sections, S2 foliation is formed by chlorite, epidote, actinolite, quartz, K-feldspar, muscovite, and subordinate small garnet, attesting to greenschists-facies conditions. Zircons are also present as accessory minerals. Dynamic recrystallization produced polygonal and inequigranular quartz grains, which often exhibit subgrains. Undulose extinction of larger quartz grains indicates crystal-plastic deformation. Lenses of 
K-feldspar porphyroclasts bounded by chlorite and micas define a mylonitic foliation. The K-feldspar fragments show intense intracrystalline deformation by brittle fracturing. Several inclusions with the presence of glaucophane are observed in the syn-tectonic K-feldspar clasts. In addition, small isolated syn-tectonic and post-tectonic garnet grains are observed. Paragneissic rocks are mainly composed of quartz, albite, chlorite, actinolite, minor micas, calcite, and garnet. Kinematically, S-C' fabrics from all samples indicate both top-to-the $\mathrm{N}$ and S shearing (Fig. 5a, b, c). Symmetric K- feldspar clasts are frequently observed, suggesting a strong coaxial component. However, in the calcite-rich ultramylonitic marble, the development of delta-type clast shows unambiguous top-to-the $\mathrm{N}$ kinematics (Fig. 5d). Similar top-to-the $\mathrm{N}$ kinematics are observed in the contact between the lower schist unit and the overlying Variegated Marble Unit defining a mylonitic shear zone in which $S / C^{\prime}$ fabric is recognized. It should be noted that near this contact, a mesocataclastic overprint is observed, producing a not more than 1.5 meters thick narrow zone of cataclasites (Fig.6a). Progressively, the main S2 foliation is folded through N-S isoclinal folds and locally crenulated. An axial planar S3 cleavage is developed, associated with an N-S intersection lineation (L3) parallel to the main N-S fold axis (B2), observed in the southern part of the island (Fig.6b).
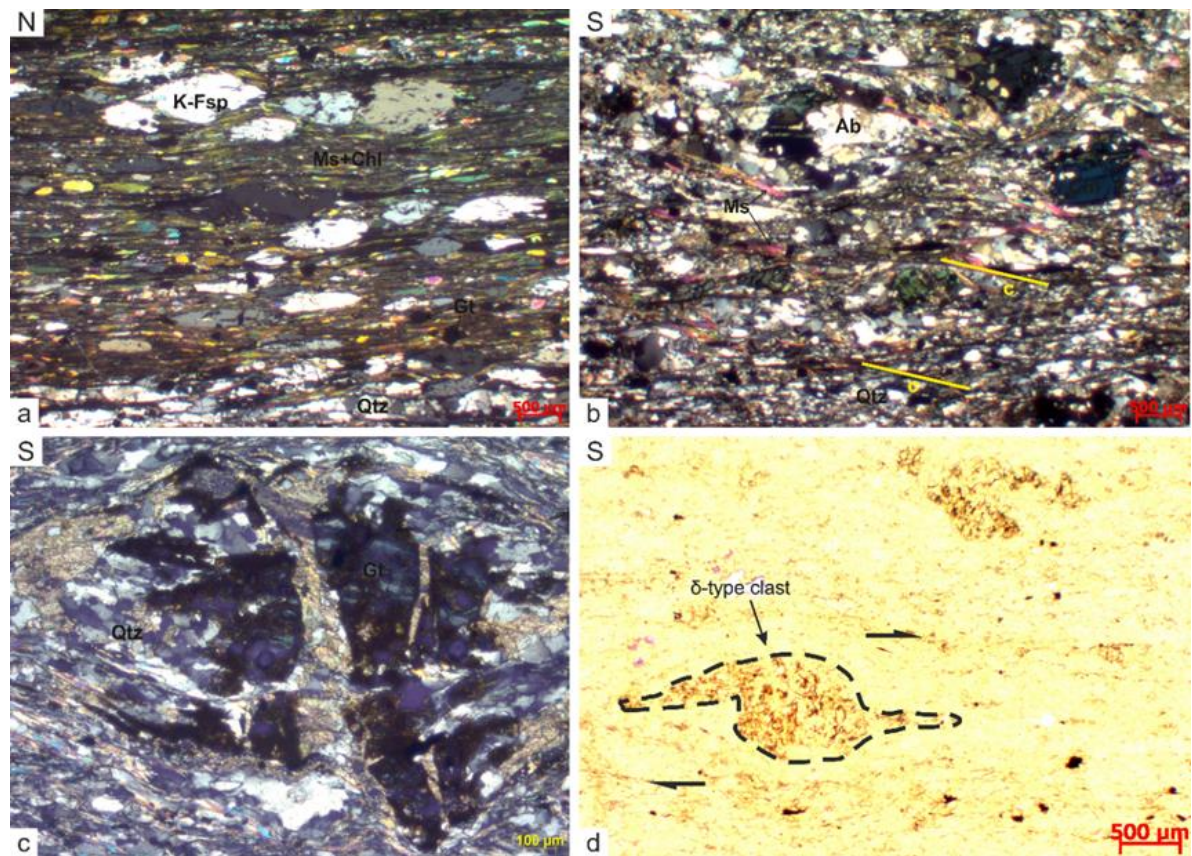

Figure 5: Thin sections (crossed polars) normal to the foliation and parallel to the stretching lineation (L2). (a) Upper Schist Unit from the southwestern Iraklia (IRA_1509) comprising K-feldspar, quartz, chlorite, epidote, muscovite and rare post-tectonic garnet. $\mathrm{S} / \mathrm{C}^{\prime}$ shear bands indicate top-to-the-north shearing, (b) Top-to-the-N S/C' shear bands in the paragneissic rock of the Lower Schist Unit (IRA_1507), (c) Boudinaged and rotated syn-tectonic garnet towards the $S$, and $(d)$ Delta-type clast indicating top-to-the N shearing.
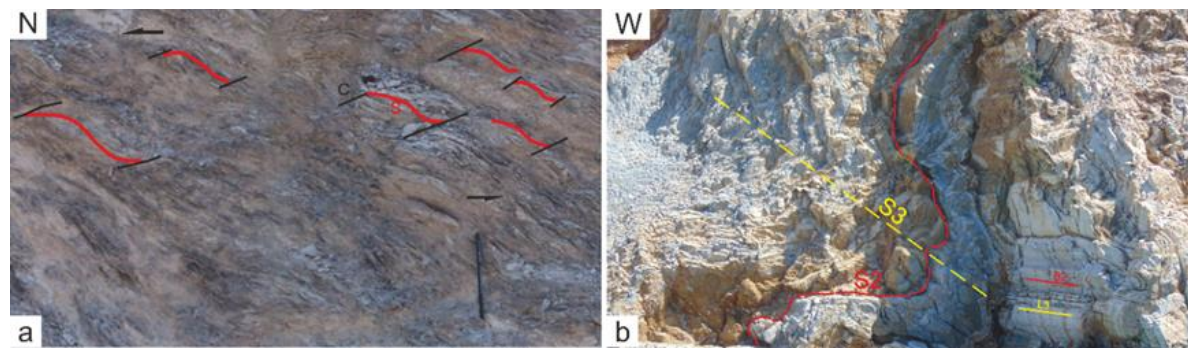
Figure 6: (a). S-C' shear bands, which are developed in the Lower Schist Unit with top-to-the-north kinematics $\left(36^{\circ} 49^{\prime} 57^{\prime \prime} N, 25^{\circ} 27^{\prime} 5^{\prime \prime} E\right)$ and (b). Axial planar cleavage (S3) in the N-S isoclinal fold and a N-S intersection/stretching lineation L3 parallel to the B2 fold axes (southern part of the island) $\left(36^{\circ} 49^{\prime} 13^{\prime \prime} N, 25^{\circ} 27^{\prime} 4^{\prime \prime} E\right)$.

\subsection{D3 Late brittle deformation}

D3 structures are related to late high-angle normal faulting that cut through all previous structures. The most significant faults are the NW-SE Vourkaria and the NE-SW Merihas fault zones (Figure 2). Kinematic indicators on the fault planes and the characteristic normal drag adjacent to the fault zones indicate a normal sense of slip.

\section{U-Pb detrital zircon dating}

\subsection{Methodology}

In this study, we performed U-Pb DZ dating on seven rock samples to define their MDAs and provenance and set constraints on the pre-subduction evolution of the metasedimentary CBU rocks of Iraklia.

Zircons were separated using standard separation techniques, including crushing and pulverizing, water table pre-concentration, magnetic separation (Frantz), and heavy liquid separations. Zircon grains were mounted on 1-inch double-sided polycarbonate rounds. About 130 zircon grains were analyzed from each sample using a laser ablationinductively coupled plasma-mass spectrometry (LA-ICP-MS) at the UT Chron Laboratory at the University of Texas at Austin, following the outlined methods [82]. GJ1 was used as primary standard (601.7 $\pm 1.3 \mathrm{Ma}$; [83]) and Plešovice as secondary standard (337.1 \pm 0.4 Ma; [84]). VisualAge Data Reduction Scheme is used in addition to Iolite v3.7 to reduce the U-Pb zircon data $[85,86]$. During data reduction, discrete age for each zircon grain was assessed to improve concordance, and U-Pb ages are reported with 2sigma error. We used detritalPy [87] for data representation and to plot samples in Kernel Density Estimates (KDE). The analytical data and calculated ages of all Iraklia samples are listed in Table S1 of the Supplementary Material.

\subsection{U-Pb Results}

In Five samples were collected from the Lower Schist Unit, three from the quartzmica schist (IRA_1801, IRA_1802, IRA_1503), and two from the paragneisses (IRA_1514, IRA_1512) (Fig.7, Supplementary Material Fig.S1). The quartz-rich schist IRA_1503 $(\mathrm{n}=108)$ from the central part of the island close to Panagia village (Pano Chorio) shows the youngest zircon $\mathrm{U}-\mathrm{Pb}$ age mode at about $559.4 \pm 2.8 \mathrm{Ma}$ (Ediacaran). This sample contains Precambrian $(100 \%)$ zircon populations with a prominent Neoproterozoic (Tonian) peak at $\sim 0.85 \mathrm{Ga}$, while minor peaks at the Paleoproterozoic/Archean boundary ( $\sim 2.5 \mathrm{Ga})$ are present. At the foot of Papas mountain, the quartz-mica schist IRA_1801 (n=130) reveals the youngest $\mathrm{DZ}$ ages at $238.2 \pm 1.5 \mathrm{Ma}$ (Carnian) with only one zircon grain at 220.1 $\pm 3.3 \mathrm{Ma}$, and zircon populations of Precambrian ( $\mathrm{n}=73,52.6 \%)$, Paleozoic $(\mathrm{n}=50,48 \%)$ and Mesozoic $(n=7,5.4 \%)$ in age. The group of Paleozoic DZ ages shows a significant Ordovician peak at $458.3 \pm 6.5 \mathrm{Ma}$. Sample IRA_1802 $(\mathrm{n}=118)$ reveals similar age spectrum to sample IRA_1801 described above with DZ distributions of Precambrian $(\mathrm{n}=54,46 \%)$, Paleozoic $(n=42,36 \%)$ and Mesozoic $(n=21,18 \%)$ in age. However, for sample IRA_1802, the youngest DZ age components are present at $204.8 \pm 2.9 \mathrm{Ma}$ (Norian), with only one zircon grain at 201.1 $\pm 5.2 \mathrm{Ma}$. Two prominent peaks are observed at $243.2 \pm 3.7 \mathrm{Ma}$ (Anisian) and $~ 435.6 \pm 7.4 \mathrm{Ma}$ (Silurian). Both samples (IRA_1801, IRA_1802) from the Lower Schist Unit yielded Early Eocene metamorphic rims at about 48-49 Ma, but two zircons from each sample also yield Late Cretaceous metamorphic rims attesting to lead loss and are not included in the metamorphic age calculations (Supplementary Material, Fig.S1). 
Additionally, from the two analyzed paragneissic rock samples, IRA_1514 (n=117) from the southern part of the island (Merihas) presents the youngest age modes at 205.4 $\pm 2.6 \mathrm{Ma}$ (Norian) with only one zircon grain at $165.4 \pm 1.8 \mathrm{Ma}$ and containing age modes in Precambrian ( $n=88,75 \%)$, Paleozoic $(n=10,8 \%)$, and Mesozoic $(n=20,17 \%)$ without any prominent peak, except for a prominent Triassic component at $\sim 233.8 \pm 2.7 \mathrm{Ma}$. Triassic zircon populations at about $\sim 226.7 \pm 3.6 \mathrm{Ma}$ (Carnian) also make up the youngest age modes of the sample IRA_1512 ( $n=120)$ from the northeastern part of the island. Precambrian zircons ( $\mathrm{n}=94,78 \%$ ) make up the majority of age modes in this sample, while it possesses a small amount of Lower Paleozoic $(n=9,7 \%)$ and Mesozoic $(n=18,15 \%)$ DZ age spectrum. A prominent Triassic peak at $231.4 \pm 1.1 \mathrm{Ma}$ and a minor peak at the Ediacaran/Cryogenian boundary are also present. Despite the similar Triassic peak of both samples (IRA_1514 and IRA_1512), as described previously, these two paragneisses show differences in the Paleozoic DZ age populations. More specifically, the sample IRA_1514 presents a small group of Silurian, Ordovician, and Devonian DZ age modes not observed in the sample IRA_1512, but instead, Carboniferous-Permian DZ age populations are represented.

Two quartz-mica schists from the Upper Schist Unit were collected from the southwestern and western parts of the island. Sample IRA_1513 $(n=105)$ shows the youngest DZ age modes at $83.4 \pm 1.2 \mathrm{Ma}$ (Campanian) with only one zircon grain at $76.1 \pm 2.8 \mathrm{Ma}$, and zircon populations are composed of Precambrian $(n=49,47 \%)$, Paleozoic $(n=42,40 \%)$ and Mesozoic ( $n=14,13 \%)$ peaks. A major peak is present at the Ordovician/Silurian boundary, while a minor Carboniferous peak is observed at 315.2 $\pm 6.1 \mathrm{Ma}$ (Pennsylvanian). Sample IRA_1511 ( $\mathrm{n}=134)$ exhibits the youngest DZ age modes at $\sim 83.5 \pm 1.1 \mathrm{Ma}$ (Campanian) with two zircon grains at 71.4 \pm 2.5 and $72.8 \pm 1.1 \mathrm{Ma}$, containing Precambrian $(n=31,23 \%)$, Paleozoic $(n=75,56 \%)$ and Mesozoic $(n=28,21 \%)$ DZ age spectrum. Both samples yield Cenozoic metamorphic rims at about 49-56 Ma (Early Eocene), similar to the rim obtained from the IRA_1802 sample (Fig.7, Supplementary Material Fig.S2).

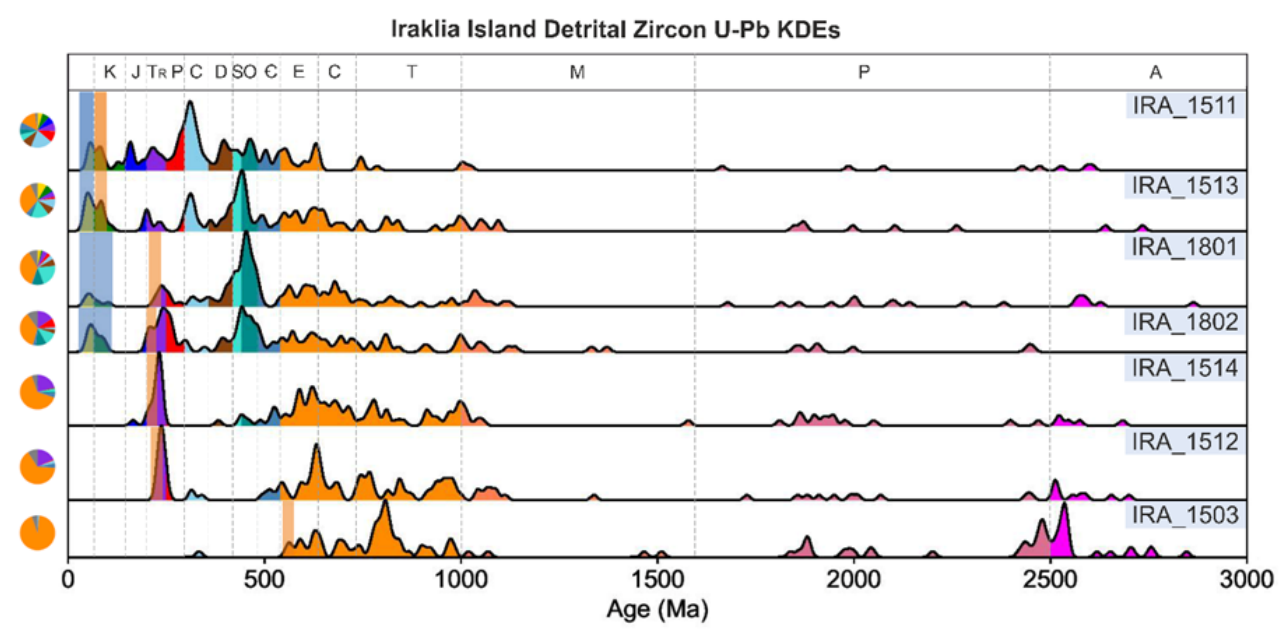

Figure 7: Detrital zircon $\mathrm{U}-\mathrm{Pb}$ KDEs results. The diagrams show the compiled data from 3000-0 Ma for each sample. MDAs and metamorphic events are depicted in lightorange and blue, respectively. The pie diagrams show the proportions of core-age components.

The $\mathrm{Th} / \mathrm{U}$ ratios in zircon grains from all Iraklia samples reveal their origin. Most detrital zircons were derived from a felsic origin, as indicated by their high $\mathrm{Th} / \mathrm{U}$ ratio (>0.1, Fig.8) for the Upper and Lower Schist Units. In contrast, only a minor component of zircons shows a metamorphic $(\mathrm{Th} / \mathrm{U}<0.1 ;$ [88]) and mafic-derived sources (Th/U>1.5, [89]). In addition, a small group of zircons is found in the transition zone between the felsic and mafic origin $(1<\mathrm{Th} / \mathrm{U}<1.5,[90,89])$. 

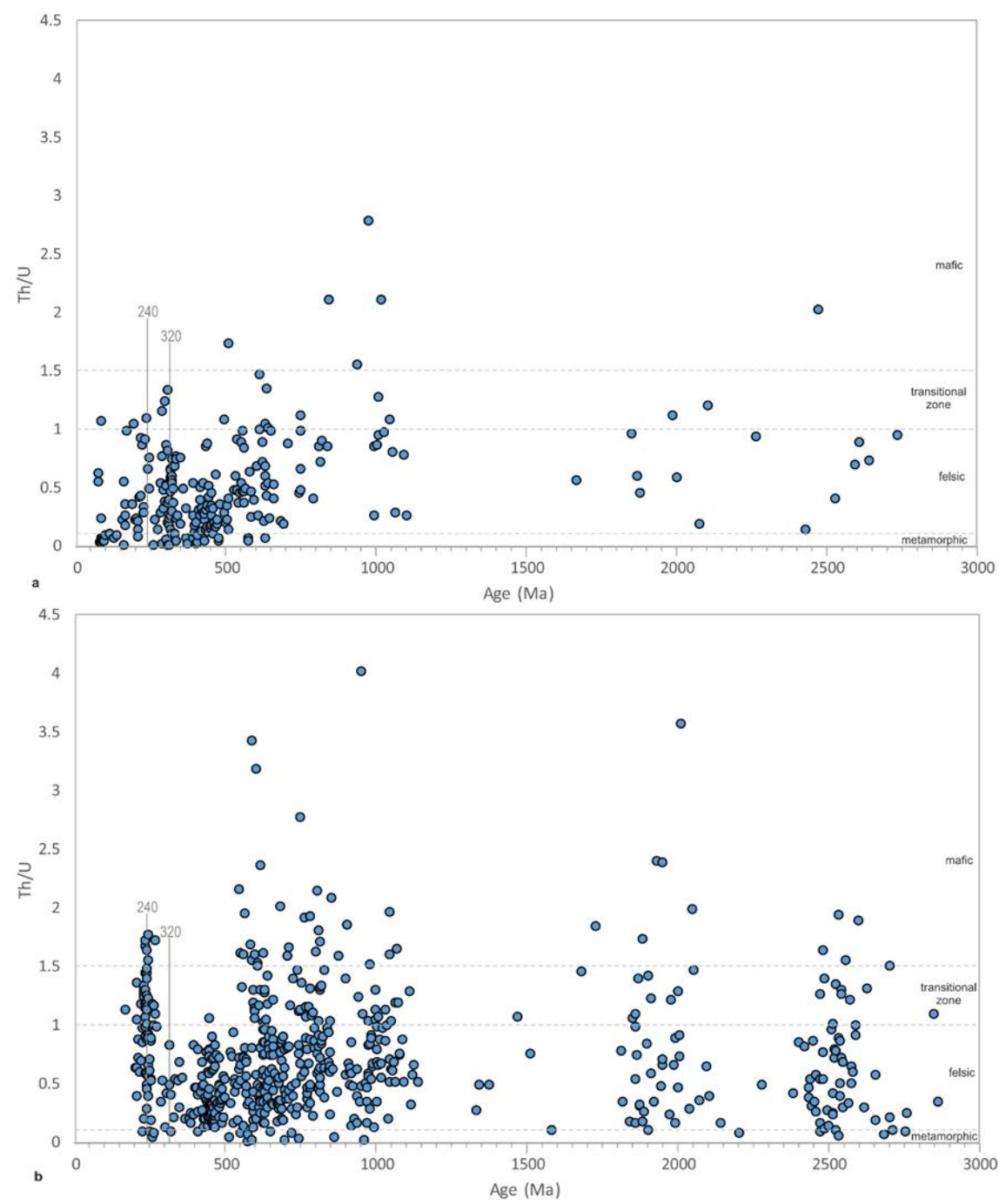

Figure 8: Zircon Th/U ratios vs. Age diagram from (a) the Upper Schist Unit and (b) the Lower Schist Unit of Iraklia island.

\section{Discussion}

\subsection{Lithostratigraphy}

The CBU rocks on Iraklia island were considered a Triassic sequence consisting of schist-marble alternations and an overlying marble unit $[16,17]$. However, our new DZ U$\mathrm{Pb}$ data allows the determination of MDAs and the investigation of the provenance of the rock units on Iraklia. Following the described method [91], the youngest age modes that overlap within error were used as MDAs calculations capable of establishing the lithostratigraphic framework. In this concept, the schists from the central and southwestern part of the island are differentiated based on their MDAs, provenance, the diverse lithological rock types, and the nature of their contacts with the intermediate Variegated Marble Unit.

The heterogeneous Lower Schist Unit consists of various lithologies, including quartz-mica schists with lenses/clasts of paragneiss rocks and quartz-rich schist. The quartz-mica schist yielded Late Triassic MDAs (Carnian-Rhaetian) ranging from 238.2 \pm 1.5 to 204.8 $\pm 2.9 \mathrm{Ma}$. The paragneisses also revealed Late Triassic MDAs (Norian-Rhaetian) at about 226.7 \pm 3.6 and 205.4 $\pm 2.6 \mathrm{Ma}$, while the quartz-rich schist yielded Precambrian (Ediacaran) MDAs at about 559.4 $\pm 2.8 \mathrm{Ma}$. The contact with the overlying Variegated Marble Unit is a ductile to brittle-ductile shear zone. Furthermore, no fossils were reported from 
the carbonate rocks, implying that the obtained Carnian-Rhaetian MDAs should be considered the lower limit for the actual depositional age. Therefore, a younger depositional age cannot be excluded; however, the major age mode from the Triassic volcanic rocks (much stronger than in the Upper Schist Unit) is indicative of a Triassic age for the Lower Schist Unit.

On the other hand, the Upper Schist Unit mainly includes quartz-mica schists that yielded Late Cretaceous MDAs of $83.5 \pm 1.12$ and 83.4 \pm 1.2 Ma (Campanian). The Late Cretaceous MDAs and the Early Eocene (Ypresian) U-Pb metamorphic rims bracket the true deposition age of the Upper Schist Unit. These schists are isoclinally folded with the underlying Variegated Marble Unit, and evidence of transition is observed in a few places. However, an isoclinally folding of an early, prograde tectonic contact cannot be excluded. Interestingly, the metabauxite occurrences within the Variegated Marble Unit at northwestern Iraklia reflect a short emersion period and characterize shallow-water platform facies. Similar metabauxites lenses have also been observed on northeastern Naxos [35] and Amorgos island [92,93]. The occurrences of Amorgos were correlated with the Cretaceous bauxites of continental Greece [94]. Thus, it is tempting to speculate a Cretaceous age for these metabauxites and the enveloping Variegated Marble Unit.

\subsection{Structures and Metamorphism}

Structural analysis on Iraklia island has shown successive deformation events related mainly to syn- and post-orogenic exhumation processes. In contrast, structures associated with the prograde path and the peak HP metamorphism are almost entirely obliterated.

The earlier HP event is recorded by relic blueschist facies minerals, such as glaucophane preserved in the Upper Schist Unit of southwestern Iraklia. Additionally, strong evidence for the HP metamorphism is supported by the new DZ U-Pb rim ages of $\sim 48-56$ Ma from the Lower and Upper Schist units. These Early Eocene HP ages are in broad agreement with ages from the HP rocks in several Cycladic islands ranging between 55$40 \mathrm{Ma}[95,96,97,98,42,11,99,100]$. Isotopic dating on Ios and SE Naxos islands has revealed an Eocene HP event at about $\sim 55-40 \mathrm{Ma}[101,102,15]$ and $40 \mathrm{Ma}$, respectively [103, 52], suggesting a prolonged HP event in the Cyclades. The Eocene zircon rims attest that the Iraklia rocks fall in the range of HP metamorphism documented on the CBU rocks regionally.

The main D2 deformation event produced N-S isoclinal folding, which resulted in the penetrative S2 foliation accompanied by the stretching lineation L2. Based on the mineral composition, the overprinting of the Iraklia CBU rocks probably did not exceed the greenschist facies P-T conditions. In contrast, Naxos island has been affected by Barrovian-type metamorphism [104,105,41,26,106,107,108].

Deformation was localized at the tectonic contact between the Lower Schist Unit and the overlying Variegated Marble Unit. Shear bands along this contact display top-to-thenorth kinematics and advocate for internal deformation within CBU rocks on Iraklia island, despite that rare top-to-the-south kinematics, have been discerned. Thus, this contact could represent a shear zone associated with exhumation processes. Furthermore, this shear zone could account for the ductile thinning of the CBU column in Iraklia. Similar ductile-brittle shear zones are described within CBU from several Cycladic islands, all related to extensional shearing [54,75,109].

\subsection{Provenance of Detrital Zircons}

The DZ age spectrum of the CBU rocks on Iraklia island represents distinct ages reflecting all the geodynamic events recorded in the broader area from Late Triassic to Late Cretaceous.

In the Lower Schist Unit, the DZ age populations include a prominent signal of Lower Paleozoic zircon, a significant contribution of Pan-African DZ ages, and a minor Late 
Paleozoic input. The combination of Precambrian and Lower Paleozoic DZ input likely reflects eroded material from peri-Gondwanan terranes and points to uplift and erosion of the pre-Variscan crystalline basement, which served as a source regionally. It should be noted that the abundant Neoproterozoic input signifies eroded rocks that contributed to several cycles of the Gondwanan-crust formation and recycling. Prominent Early Paleozoic-Neoproterozoic ages are also ascertained from CB rocks in the southern Cyclades $[20,14,15]$. Moreover, early exhumation of basement rocks has also been described from both the southern Cyclades (e.g., Ios, [14]) and the Pelagonian domain [110]. This assumption is also reinforced by the quartz-rich schist layer within the Lower Schist Unit. The exclusively Pan-African DZ age spectrum of the quartz-rich schist that yielded Precambrian MDAs (Ediacaran) could reflect rocks involved in the East African orogeny (Transgondwana supercontinent and Sahara metacraton) [111,112]. The high amount of Tonian $\mathrm{DZ}$ ages with a pronounced peak at $\sim 0.850$ Ga pertain to the described Minoan terranes, characterizing the basement rocks exposed on the External Hellenides $[113,114,115,116,117]$. On Ios island, Precambrian metasedimentary sequences yielded similar MDAs and Pan-African provenance. They represent slivers of the pre-Carboniferous metasedimentary rocks of the $\mathrm{CB}$ intruded by the voluminous Carboniferous granitoids [14]. The minor Late Paleozoic input of the Lower Schist Unit likely reflects eroded material that has been involved in the Variscan orogeny along the active Eurasian margin in response to Paleotethys closure. Late Carboniferous- Early Permian magmatism characterize the basement rocks in the Cyclades $[70,118,45,119,14,15]$, the external Hellenides and Pelagonian domain $[110,120,113,121,116]$.

The Triassic input, associated with the Triassic magmatic activity, is significant in the paragneissic rocks and the quartz-mica schist of the Lower Schist Unit. The prominent Ladinian-Carnian peaks in the paragneisses reflect the continuous magmatic activity. Based on the measured $\mathrm{Th} / \mathrm{U}$ ratios, most of the Triassic dated detrital zircons (at about $\sim 240 \mathrm{Ma}$ ) have originated from rocks with felsic and intermediate composition with only a few mafic-derived zircons, attesting to the closure of the Paleotethys and the opening of the Neotethyan oceanic basin (e.g., Pindos basin, southern Neotethys, 122,123,124,125, $116,117)$. Nonetheless, a striking feature of the Lower Schist Unit is the significant similarity regarding the MDAs and provenance source areas with the described metasedimentary and basement rocks on Ios and Sikinos islands $[14,15]$ implying their close spatial relationship.

The Upper Schist Unit with Late Cretaceous MDAs, exhibit DZ age spectra that show much less Proterozoic and a high amount of Late Paleozoic-Mesozoic age distributions. However, the Early Paleozoic is still significant. The abundant Late Paleozoic-Mesozoic age modes probably reflect recycled crystalline basement and metasedimentary rocks from the Pelagonian domain and/or more internal areas as source rocks. Interestingly, the $\mathrm{Th} / \mathrm{U}$ ratios show that most Cretaceous detrital zircons indicate metamorphic origin, while a low amount of felsic-derived zircons is observed. These schists show similarities in provenance with the Late Cretaceous schists, described on the CBU rocks from the Western Cyclades [25], northern Ios and Sikinos [15], and/or to the latest Cretaceous passive-margin sequence of Naxos island [126,49,51].

\subsection{Regional Implications}

A provenance-based correlation between the CBU rocks of Iraklia and the neighboring islands can give insights into the paleogeography before the Cenozoic tectonometamorphic evolution and further provide important information about the pre-subduction history of the island from the Middle-Late Triassic to Late Cretaceous (Fig.9).

Our new data demonstrate that the CBU rocks of Iraklia were initially deposited in an isolated Late Triassic basin, receiving mainly recycled Godwanan-derived zircons. This indicates that pre-Variscan and older basement rocks underwent uplift and erosion, supplying the sedimentary rocks of the Lower Schist Unit. During that time, deposition was 
also accompanied by locally recycled volcanic input, probably related to the magmatism associated with two different regional geodynamic events: a) the final closure of southern Paleotethys that took place in Ladinian- Early Carnian and b) the early rifting stages and the opening of Neotethyan basins (e.g. Pindos basin, southern Neotethys, $[127,128$, $122,123,70,118,45,124,125,116,117,14,15]$. These Late Triassic MDAs with Pan-African affinity imply that sedimentation occurred in a proximal position with Ios island, evidenced by the similar Late Triassic metasedimentary rocks observed on both islands, suggesting for an equivalent lithological unit, despite that sedimentation in northern Ios probably started earlier during Permian time [15]. The close spatial relationship is also supported by the quartz-rich schist, characterized exclusively by Precambrian DZ ages. It probably originates from Ios pre-Variscan metasedimentary CB rocks and strengthens arguments for an early exhumation of crystalline basement rocks in a broad area. Sedimentation in a passive margin is continued with deposition of shallow-water carbonates probably of (?Jurassic-)Cretaceous age, interrupted by short emersion episodes and bauxite deposits.

The final depositional history of Iraklia CBU rocks is marked by the Late Cretaceous quartz-mica schists that are correlated nicely with those from northern Ios [15] and Naxos $[126,49]$ islands, exhibiting a pronounced change in provenance dominated by MesozoicLate Paleozoic and a low amount of Neoproterozoic age distributions. Sediments were likely derived from rocks exposed in the internal Hellenides, including the Pelagonian domain and Rhodope belt, and possibly correspond to clastic sedimentation before or during the onset of subduction.

Relic of glaucophane and the rim ages obtained from both schist units indicate that the Iraklia CBU rocks experienced an Early Eocene HP event, overprinted by a younger greenschists facies metamorphism similar to Ios island [129,73,74]. However, they were not affected by the migmatitic dome high-grade metamorphism observed in the Naxos MCC $[104,106]$. Several kinematic indicators suggest a dominant top-to-the $\mathrm{N}$ shearing for the main greenschist facies deformation event. However, top-to-the $S$ kinematics are also observed. Since there are no cross-cutting relationships between the top-to-the-north and south kinematics, a possible scenario for the opposing kinematics could be related to a general shear deformation pattern. In this concept, a correlation with the N-PDS could be inferred. Alternatively, the top-to-the $\mathrm{S}$ kinematics could be associated with the South Cycladic Shear Zone [58,74,60] and/or the Santorini Detachment System [13] active concomitantly with the N-PDS.

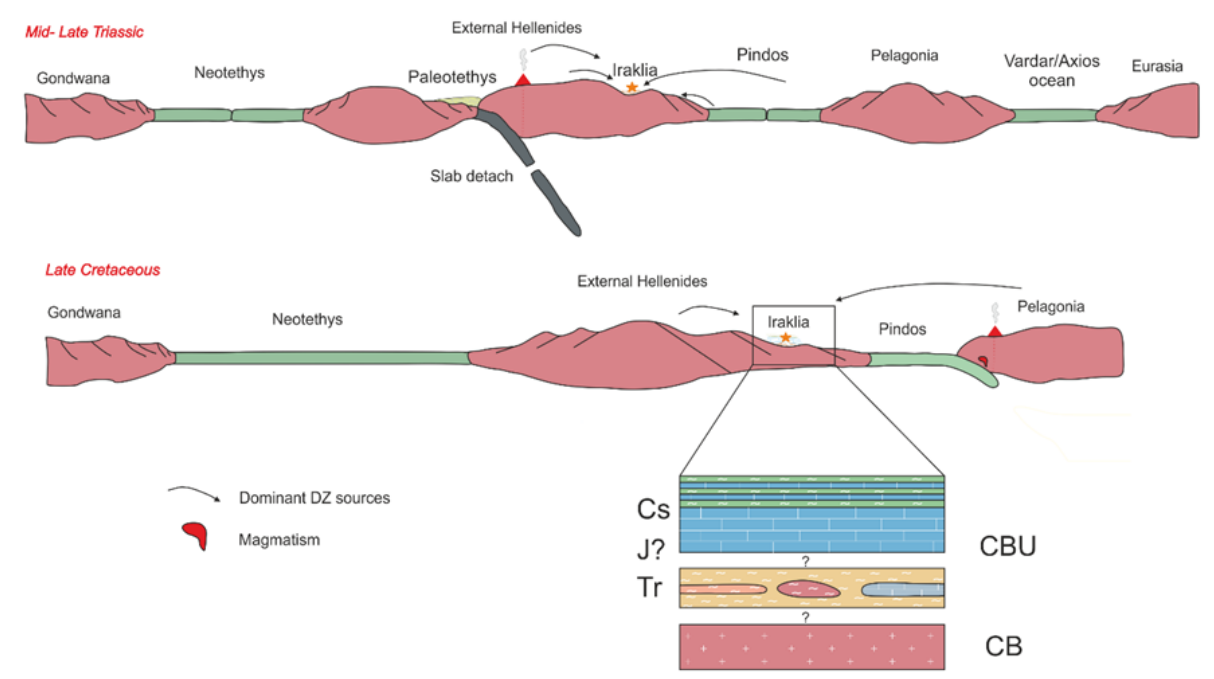

Figure 9: Schematic paleogeographic reconstruction of Iraklia island from MiddleLate Triassic to Late Cretaceous time.

\section{Conclusions}


- The tectonostratigraphic column of Iraklia includes a lower meta-clastic sequence of probable mid-late Triassic age juxtaposed with a top to $\mathrm{N}$ ductile shear zone against an overlying variegated marble - quartz-mica schist sequence of likely Late Cretaceous age.

- $\quad$ DZ U-Pb ages from the Lower Schist Unit revealed a dominant Precambrian and Lower Paleozoic input. The Upper Schist Unit has shown prominent Late Paleozoic and Mesozoic DZ age distributions.

- $\quad$ The U-Pb rim ages revealed an early Eocene HP metamorphic event compared to the neighboring Ios and Naxos islands.

- The Lower and Upper Schist Units of Iraklia bear significant similarities with the Triassic and Cretaceous schists, respectively, from Ios and Sikinos islands, suggesting their close relationship during deposition.

Supplementary Material: The following are available online at www.mdpi.com/xxx/s1, Table S1: U-Pb detrital zircon analyses from Iraklia Island, central Cyclades, Greece, Figure S1: Representative photos of collected samples from Iraklia island: a) Precambrian quartz-mica schist, b) Middle-Late Triassic quartz-mica schist, c) Middle-Late Triassic paragneiss, and d) Late Cretaceous quartz-mica schist, Figure S2: Rim ages and MSWDs calculated by the weighted mean of ${ }^{206} \mathrm{~Pb} / 238 \mathrm{U}$ ages for concordance. IsoplotR was used for calculations [130].

\section{Author Contributions:}

S. Laskari project conception, investigation, lab analyses, writing-original draft preparation; $\mathrm{K}$. Soukis project conception, investigation, editing; S. Lozios investigation, editing; D.F. Stockli, lab analyses investigation, editing; E.M. Poulaki, lab analyses investigation, editing and Ch Stouraiti investigation, editing.

Funding: This research did not receive funding.

Acknowledgments: The authors are grateful to Lisa Stockli, Daniel Arnost, and Spencer Seman for their invaluable assistance in the UTChron laboratory.

Conflicts of Interest: The authors declare no conflict of interest.

\section{References}

1. Lister, G.S., Banga, G., Feenstra, A. 1984. Metamorphic core complexes of Cordilleran type in the Cyclades Aegean Sea, Greece. Geology 12, 221-225.

2. Bröcker, M., Kreuzer, H., Matthews, A., and Okrusch, M. 1993. 40Ar/39Ar and oxygen isotope studies of polymetamorphism from Tinos Island, Cycladic blueschist belt, Greece: J. Metamorph. Geol., 11, 223-240, doi:10.1111/j.1525-1314.1993. tb00144. x.

3. Gautier, P., and Brun, J.P. 1994. Crustal-scale geometry and kinematics of late-orogenic extension in the central Aegean (Cyclades and Ewia Island). Tectonophysics, 238(1-4), 399-424. DOI:10.1016/0040-1951(94)90066-3.

4. Bröcker, M., and Franz, L. 1998. Rb-Sr isotope studies on Tinos Island (Cyclades, Greece): additional time constraints for metamorphism, extent of infiltration-controlled overprinting and deformational activity. Geol. Mag., 135, 369-382.

5. Brichau, S., Ring, U., Carter, A., Monié, P., Bolhar, R., Stockli, D., Brunel, M. 2007. Extensional faulting on Tinos Island, Aegean Sea, Greece: How many detachments? Tectonics, 26, TC4009.

6. Jolivet, L., and Brun, J.P. 2010. Cenozoic geodynamic evolution of the Aegean. Int. J. Earth Sci., (Geol. Rundsch.), 99(1), 109-138.

7. Jolivet, L., Lecomte, E., Huet, B., Denèle, Y., Lacombe, O., Labrousse, L., Le Pourhiet, L., Mehl, C. 2010. The North Cycladic detachment system. Earth Planet. Sci. Lett., 289, 87-104.

8. Ring, U., Glodny, J., Will, T., and Thomson, S. 2010. The Hellenic Subduction System: High-Pressure Metamorphism, Exhumation, Normal Faulting, and Large-Scale Extension. Ann. Rev. Earth Planet. Sci., 38(1), 45-76.

9. Grasemann, B., Schneider, D.A., Stockli, D.F., and Iglseder, C. 2012. Miocene bivergent crustal extension in the Aegean: Evidence from the western Cyclades (Greece). Lithosphere, 4(1), 23-39. 
10. Soukis, K., and Stockli, D.F. 2013. Structural and thermochronometric evidence for multi-stage exhumation of southern Syros, Cycladic islands, Greece. Tectonophysics, 595, 148-164.

11. Huet, B., Labrousse, L., Monjé, P., Malvoisin, B., \& Jolivet, L. 2014. Coupled phengite 40Ar-39Ar geochronology and thermobarometry: PTt evolution of Andros Island (Cyclades, Greece). Geol. Mag., 152(4), 711-727. https://doi.org/10.1017/ S0016756814000661.

12. Malandri, C., Soukis, K., Maffione, M., Özkaptan, M., Vassilakis, E., Lozios, S., \& van Hinsbergen, D. J. 2017. Vertical-axis rotations accommodated along the Mid-Cycladic lineament on Paros Island in the extensional heart of the Aegean orocline (Greece). Lithosphere, 9(1), 78-99. https://doi.org/10.1130/L575.1.

13. Schneider, D.A., Grasemann, B., Lion, A., Soukis, K., Draganits, E. 2018. Geodynamic significance of the Santorini Detachment System (Cyclades, Greece). Terra Nova 30, 414-422, DOI:410.1111/ter.12357.

14. Flansburg, M.E., Stockli, D.F., Poulaki, E.M., and Soukis, K. 2019. Tectono-magmatic and stratigraphic evolution of the Cycladic Basement, Ios Island, Greece. Tectonics, 38, 2291-2316. https://doi.org/10.1029/2018tc005436.

15. Poulaki, E.M., Stockli, D.F., Flansburg, M.E., and Soukis, K. 2019. Zircon U-Pb chronostratigraphy and provenance of the Cycladic Blueschist Unit and Cycladic Basement on Sikinos and Ios Islands, Greece. Tectonics. https://doi.org/10.1029/2018TC005436.

16. Avdis, V. \& Triantaphyllis, M. 1994. Geological Map, sheets Iraklia and Schinoussa, Scale 1: 50 000. - Department of Geology and Geological Mapping, Athens.

17. Behrmann, J.H., Seckel, C. 2007. Structures, flow stresses, and estimated strain rates in metamorphic rocks of the Small Cyclades Islands Iraklia and Schinoussa (Aegean Sea, Greece). Geotectonica Res. 95, 1-11.

18. Papanikolaou, D. 1987. Tectonic evolution of the Cycladic blueschist belt (Aegean Sea, Greece). In: Helgeson H.C. (ed.) Chemical transport in metasomatic processes. D. Reidel Publ. Com., Dordrecht, 429-450.

19. Henjes-Kunst, F., \& Kreuzer, H. 1982. Isotopic dating of pre-alpidic rocks from the island of Ios (Cyclades, Greece). Contr. Mineral. Petrol., 80(3), 245-253. https://doi.org/10.1007/BF00371354.

20. Keay, S., and Lister, G. 2002. African provenance for the metasediments and meta-igneous rocks of the Cyclades, Aegean Sea, Greece. Geology, 30(3), 235-238.

21. Bröcker, M., and Pidgeon, R.T. 2007. Protolith Ages of Meta-igneous and Metatuffaceous Rocks from the Cycladic Blueschist Unit, Greece: Results of a Reconnaissance U-Pb Zircon Study. J. Geol., 115, 83-98.

22. Löwen, K., Bröcker, M., and Berndt, J. 2015. Depositional ages of clastic metasediments from Samos and Syros, Greece: Results of a detrital zircon study. Int. J. Earth Sci., 104(1), 205-220. https://doi.org/10.1007/s00531-014-1058-x.

23. Bröcker, M., Huyskens, M., and Berndt, J. 2016. U-Pb dating of detrital zircons from Andros, Greece: constraints for the time of sediment accumulation in the northern part of the Cycladic blueschist belt. Geol. J., 51(3), 354-367. https://doi.org/10.1002/gj.2634.

24. Hinsken, T., Bröcker, M., Berndt, J., and Gärtner, C. 2016. Maximum sedimentation ages and provenance of metasedimentary rocks from Tinos Island, Cycladic blueschist belt, Greece. Int. J. Earth Sci., 105(7), 1923-1940. https://doi.org/10.1007/s00531-0151258-z.

25. Seman, S., Stockli, D.F., and Soukis, K. 2017. The provenance and internal structure of the Cycladic Blueschist Unit revealed by detrital zircon geochronology, Western Cyclades, Greece. Tectonics, 36, 1407-1429 https://doi.org/10.1002/2016TC004378.

26. Avigad, D., and Garfunkel, Z. 1991. Uplift and exhumation of high-pressure metamorphic terranes: The example of the Cycladic blueschists belt (Aegean Sea). Tectonophysics, 188, 357-372.

27. Pe-Piper, G., and Piper, D.J.W. 2002. The igneous rocks of Greece. The anatomy of an orogen. Gebr. Borntraeger, Berlin, pp 1573. 
28. Soukis, K., and Papanikolaou, D., 2004. Contrasting geometry between Alpine and late- to post-Alpine tectonic structures in Anafi Island (Cyclades). Bull. Geol. Soc. Greece, 36(4), 1688-1696.

29. Lekkas, S., Skourtsos, Em., Soukis, K., Kranis, H., Lozios, S.G., Alexopoulos, A. and Koutsovitis, P. 2011. Late Miocene detachment faulting and crustal extension in SE Attica (Greece). Geoph. Res. Abstr., 13, EGU-2011-13016, 2011.

30. Grasemann, B., Schneider, D.A., Soukis, K., Roche, V., Hubmann B. 2021. Paleogeographic position of the central Dodecanese Islands, southeastern Greece: The push-pull of Pelagonia. Geol. Soc. Am. Bull 2021, doi:https://doi.org/10.1130/B36095.1.

31. Royden, L. H. 1993. Evolution of retreating subduction boundaries formed during continental collision, Tectonics, 12(3), 629638, doi:10.1029/92TC02641.

32. Dürr, S., Altherr, R., Keller, J., Okrusch, M., Seidel, E. 1978. The Median Aegean Crystalline Belt: Stratigraphy, structure, metamorphism, magmatism, in: Closs, H. et al. (Eds.), Alps, Apennines, Hellenides. IUCG Sci. Rep. 38, 455-477.

33. Böger, H. 1983. Stratigraphische und tektonische Verknuepfungen kontinentaler Sedimente des Neogens im Aegais-Raum. Geol. Rundsch., 72, 771-813.

34. Menant, A., Jolivet, L., Vrielynck, B. 2016. Kinematic reconstructions and magmatic evolution illuminating crustal and mantle dynamics of the eastern Mediterranean region since the late Cretaceous. Tectonophysics, 675, 103-140.

35. Jansen, J.B.H. 1977. Metamorphism on Naxos, Greece, thesis, Utrecht Univ., Utrecht, Netherlands.

36. Papanikolaou, D.J. 1978. Contribution to the geology of Aegean Sea. The Island of Andros. Ann. Géol. Pays Hellén., 29, 477-553.

37. Blake, M.C., Geyssant, J., Kienast, J.R., Lepvrier, C., Maluski, H., Papanikolaou, D. 1981. A geologic reconnaissance of the Cycladic Blueschist Belt, Greece. Geol. Soc. Am. Bull., 92 (I), 247-254.

38. Bröcker, M. 1990. Die Blauschiefer-Grünschiefer-Assoziation der Insel Tinos (Kykladen, Griechenland) und ihre kontaktmetamorphe Überprägung. Geotektonische Forschungen, 74, 1-107.

39. Keiter, M., Ballhaus, C., \& Tomaschek, F. 2011. A new geological map of the Island of Syros (Aegean Sea, Greece): Implications for lithostratigraphy and structural history of the Cycladic Blueschist Unit. Geol. Soc. Am. Bull., Vol. 481.

40. Bonneau, M., \& Kienast, J. R. 1982. Subduction, collision et schistes bleus; l'exemple de l'Egee (Grece). Bull. Soc. geol. Fr., 7(4), 785-791.

41. Wijbrans, J.R., and McDougall, I. 1988. Metamorphic evolution of the Attic Cycladic Metamorphic belt on Naxos (Cyclades, Greece) utilizing 40Ar/39Ar age spectrum measurements. J. Metamorph. Geol., 6 (1988) 57 I-594.

42. Lagos, M., Scherer, E. E., Tomaschek, F., Münker, C., Keiter, M., Berndt, J., \& Ballhaus, C. 2007. High precision Lu-Hf geochronology of Eocene eclogite-facies rocks from Syros, Cyclades, Greece. Chem. Geol., 243(1-2), 16-35.

43. Kotowski, A.J., Behr, W.M., Cisneros, M., Stockli, D.F., Soukis, K., Barnes, J. and Ortega-Arroyo, D., 2020. Subduction, underplating, and return flow recorded in the Cycladic Blueschist Unit exposed on Syros Island, Greece. Earth and Space Science Open Archive ESSOAr.

44. Ring, U., Pantazides, H., Glodny, J. and Skelton, A., 2020. Forced return flow deep in the subduction channel, Syros, Greece. Tectonics, 39(1), p.e2019TC005768, https://doi.org/10.1029/2019TC005768.

45. Keay, S., Lister, G., Buick, I. 2001. The timing of partial melting, Barrovian metamorphism and granite intrusion in the Naxos metamorphic core complex Cyclades, Aegean Sea, Greece. Tectonophysics, 342, 275-312.

46. Denèle, Y., Lecomte, E., Jolivet, L., Lacombe, O., Labrousse, L., Huet, B., Le Pourhiet, L. 2011. Granite intrusion in a metamorphic core complex: the example of the Mykonos laccolith (Cyclades, Greece). Tectonophysics, 501, 52-70.

47. Beaudoin, A., Laurent, V., Augier, R., Jolivet, L., Lahfid, A., Arbaret, L., Rabillard, A., Menant, A. 2015. The Ikaria high-temperature metamorphic core complex (Cyclades, Greece): geometry, kinematics and thermal structure. J. Geodyn., 92, 18-41. 
48. Laurent, V., Beaudoin, A., Jolivet, L., Arbaret, L., Augier, R., Rabillard, A., Menant, A. 2015. Interrelations between extensional shear zones and synkinematic intrusions: the example of Ikaria Island (NE Cyclades, Greece). Tectonophysics 651-652, 152-171.

49. Cao, S.Y., Neubauer, F., Bernroider, F., Genser, J., Liu, J., Friedl, G., 2017. Low-grade retrogression of a high-temperature metamorphic core complex: Naxos, Cyclades, Greece. Geol. Soc. Am. Bull., 129, 93-117. https://doi.org/10.1130/B31502.1.

50. Peillod, A., Ring, U., Glodny, J., Skelton, A. 2017. An Eocene/Oligocene blueschist-/greenschist-facies P-T loop from the Cycladic Blueschist unit on Naxos island, Greece: deformation-related reequilibration vs thermal relaxation. J. Metamorph. Geol., 35, 805830.

51. Ring, U., Glodny, J., Pelliod A., Skelton A. 2018. The timing of high-temperature conditions and ductile shearing in the footwall of the Naxos extensional fault system, Aegean Sea, Greece. Tectonophysics, 700, 108-130.

52. Ring, U., Thompson, S. \& Brocker, M. 2003. Fast extension but little exhumation: the Vari detachment in the Cyclades, Greece. Geol. Mag., 140 (3), 245-252.

53. Xypolias, P., Kokkalas, S., \& Skourlis, K. 2003. Upward extrusion and subsequent transpression as a possible mechanism for the exhumation of HP/LT rocks in Evia Island (Aegean Sea, Greece). J. Geodyn., 35(3), 303-332.

54. Huet, B., Labrousse, L., and Jolivet, L. 2009. Thrust or detachment? exhumation processes in the Aegean: Insight from a field study on Ios (Cyclades, Greece). Tectonics, 28(3), 1-27.

55. Xypolias, P., Iliopoulos, I., Chatzaras, V., and Kokkalas, S. 2012. Subduction- and exhumation-related structures in the Cycladic Blueschists: Insights from south Evia Island (Aegean region, Greece). Tectonics, 31, TC2001.

56. Bargnesi, E.A., Stockli, D.F., Mancktelow, N., and Soukis, K. 2013. Miocene core complex development and coeval supradetachment basin evolution of Paros, Greece, insights from (U-Th)/He thermochronometry. Tectonophysics, 595, 165-182.

57. Roche, V., Laurent, V., Cardello, G.L., Jolivet, L., Scaillet, S. 2016. Anatomy of the Cycladic Blueschist Unit on Sifnos Island (Cyclades, Greece). J. Geodyn., 97, pp.62-87

58. Vandenberg, L. C., and Lister, G. S. 1996. Structural analysis of basement tectonites from the Aegean metamorphic core complex of Ios, Cyclades, Greece. J. Struct. Geol., 18(12), 1437-1454. https://doi.org/10.1016/S0191-8141(96)00068-5.

59. Philippon, M., Brun, J.P. and Gueydan, F. 2012. Deciphering subduction from exhumation in the segmented Cycladic Blueschist unit (Central Aegean, Greece). Tectonophysics, 524, pp.116-134.

60. Mizera, M. and Behrmann, J.H. 2016. Strain and flow in the metamorphic core complex of Ios Island (Cyclades, Greece). Int. J. Earth Sci., 105(7), pp.2097-2110.

61. Coleman, M., Dubosq, R., Schneider, D.A., Grasemann, B. and Soukis, K. 2019. Along-strike consistency of an extensional detachment system, West Cyclades, Greece. Terra Nova, 31(3), pp.220-233.

62. Coleman, M.J., Schneider, D.A., Grasemann, B., Soukis, K., Lozios, S. and Hollinetz, M.S. 2020. Lateral Termination of a Cycladic-Style Detachment System (Hymittos, Greece). Tectonics, 39, e2020TC006128.

63. Altherr, R., Kreuzer, H., Lenz, H., Wendt, I., Harre, W., \& Dürr, S. 1994. Further evidence for a Late Cretaceous low-pressure/high-temperature terrane in the Cyclades, Greece. Chemie der Erde, 54, 319-328.

64. Bolhar, R., Ring, U., \& Allen, C. M. 2010. An integrated zircon geochronological and geochemical investigation into the Miocene plutonic evolution of the Cyclades, Aegean Sea, Greece: Part 1: Geochronology. Contr. Mineral. Petrol., 160(5), $719-742$.

65. Papanikolaou, D.J., 1977. Contribution to the geology of the Aegean Sea: the island of Andros. Ann. Geol. Pays Hell., 29, 477-553.

66. Papanikolaou D. 1980. Contribution to the geology of Aegean Sea. The island of Paros, Ann. Géol. Pays Hellén., 30(1), 65-96.

67. van der Maar, P. A. 1981. Metamorphism on Ios and the geological history of the southern Cyclades, Greece (Doctoral dissertation, Utrecht University). 
68. Andriessen, P.A.M., Banga, G. and Hebeda, E.H., 1987, Isotopic age study of pre-Alpine rocks in the basal units on Naxos, Sikinos and Ios, Greek Cyclades. Geol. Mijnb., 66(3), pp.3-14.

69. Engel, M., and Reischmann, T. 1998. Single zircon geochrology of orthogneisses from Paros, Greece. Bull. Geol. Soc. Greece, 32(3), 91-99.

70. Reischmann, T. 1998. Pre alpine origin of tectonic units from the metamorphic complex of Naxos, Greece, identified by single zircon $\mathrm{Pb} / \mathrm{Pb}$ dating. Bull. Geol. Soc. Greece, 32(3), 101-111.

71. Zlatkin, O., Avigad, D., and Gerdes, A. 2018. New Detrital Zircon Geochronology from the Cycladic Basement (Greece): Implications for the Paleozoic Accretion of Peri-Gondwanan Terranes to Laurussia. Tectonics, 37(12), 4679-4699. https://doi.org/10.1029/2018TC005046.

72. Forster, M. A., \& Lister, G. S. 1999. Detachment faults in the Aegean core complex of Ios, Cyclades, Greece. Geol. Soc., Lond on, Spec. Publ., 154(1), 305-323. https://doi.org/10.1144/GSL.SP.1999.154.01.14.

73. Forster, M., \& Lister, G. 2009. Core-complex-related extension of the Aegean lithosphere initiated at the Eocene-Oligocene transition. J. Geophys. Res., 114, B02401. https://doi.org/10.1029/2007JB005382.

74. Thomson, S.N., Ring, U., Brichau, S., Glodny, J. and Will, T.M., 2009. Timing and nature of formation of the Ios metamorphic core complex, southern Cyclades, Greece. Geol. Soc. London, Spec. Publ., 321(1), pp.139-167, https://doi.org/10.1144/SP321.7.

75. Augier, R., Jolivet, L., Gadenne, L., Lahfid, A., and Driussi, O. 2014. Exhumation kinematics of the Cycladic Blueschists unit and back-arc extension, insight from the Southern Cyclades (Sikinos and Folegandros Islands, Greece). Tectonics, 34(1), $152-185$.

76. Keay, S. (1998). The geological evolution of the Cyclades, Greece: constraints from SHRIMP U-Pb geochronology. PhD Thesis. DOI:10.25911/5d66671ad2b2f.

77. Angelier, J., Glaçon, G., Muller, C., 1978. Sur la présence et la position tectonique du Miocène inférieur marin dans l'archipel de Naxos (Cyclades, Grèce). Comptes Rendus. Acad. Sci., 286, 21-24.

78. Reinecke, T., Altherr, R., Hartung, B., Hatzipanagiotou, K., Kreuzer, H., Harre, W., Klein, H., Keller, J., Geenen, E., Böger, H. 1982. Remnants of a late Cretaceous high temperature belt on the island of Anafi (Cyclades, Greece). Neues Jb. Mineral. Abh., $145,157-182$.

79. Bonneau, M. 1984. Correlation of the Hellenic nappes in the south-east Aegean and their tectonic reconstruction. In: Dixon, J.E., Robertson, A.H.F. (Eds.). The Geological Evolution of the Eastern Mediterranean. Special Publication of the Geological Society of London. Blackwell Sci. Publ., Oxford, pp. 517-527.

80. Sanchez-Gomez, M., Avigad, D., Heimann, A. 2002. Geochronology of clasts in allochthonous Miocene sedimentary sequences on Mykonos and Paros Islands: implications for back-arc extension in the Aegean Sea. J. Geol. Soc., 159, 45-60.

81. Brodhag, S., Gracia-Calvo, M. \& Schiwek, P., 2003: Geologie und Tektonik der Insel Iraklia/Kykladen (Griechenland). - Unpubl.nMapping Report, Univ. Freiburg, 76 pp.

82. Marsh, J.H., and Stockli, D.F. 2015. Zircon U-Pb and trace element zoning characteristics in an anatectic granulite domain: Insights from LASS-ICP-MS depth profiling. Lithos, 239, 170-185.

83. Jackson, S.E., Pearson, N.J., Griffin, W.L., and Belousova, E.A. 2004. The application of laser ablation-inductively coupled plasma-mass spectrometry to in situ U-Pb zircon geochronology. Chem. Geol., 211(1-2), 47-69.

84. Sláma, J., Košler, J., Condon, D.J., Crowley, J.L., Gerdes, A., Hanchar, J.M., and Schaltegger, U. 2008. Plešovice zircon-a new natural reference material for $\mathrm{U}-\mathrm{Pb}$ and $\mathrm{Hf}$ isotopic microanalysis. Chem. Geol., 249(1-2), 1-35.

85. Paton, C., Woodhead, J.D., Hellstrom, J.C., Hergt, J. M., Greig, A., and Maas, R. 2010. Improved laser ablation U-Pb zircon geochronology through robust downhole fractionation correction. Geochem., Geophys., Geosyst., 11(3) Q0AA06, doi:10.1029/2009GC002618.

86. Petrus, J.A., and Kamber, B.S. 2012. VizualAge: A novel approach to laser ablation ICP-MS U-Pb geochronology data reduction. Geostand. Geoanal. Res., 36(3), 247-270. 
87. Sharman, G.R., Sharman, J.P. and Sylvester, Z. 2018. DetritalPy: A Python-based toolset for visualizing and analysing detrital geo-thermochronologic data. The Depositional Record, 4(2), pp.202-215.

88. Rubatto, D. 2002. Zircon trace element geochemistry: Partitioning with garnet and link between U-Pb ages and metamorphism. Chem. Geol., 184, 123-138.

89. Linnemann, U., Ouzegane, K., Drareni, A., Hofmann, M., Becker, S., Gärtner, A. and Sagawe, A. 2011. Sands of West Gondwana: an archive of secular magmatism and plate interactions - a case study from the Cambro-Ordovician section of the Tassili Ouan Ahaggar (Algerian Sahara) using U-Pb-LA-ICP-MS detrital zircon ages. Lithos, 123(1-4), pp.188-203.

90. Hoskin, P.W.O. and Schaltegger, U. 2003. The composition of zircon and igneous and metamorphic petrogenesis. In Reviews in Mineralogy and Geochemistry; Mineral. Soc. Am., Washington, DC, USA, Volume 53, pp. 27-55.

91. Dickinson, W. R., \& Gehrels, G. E. 2009. Use of U-Pb ages of detrital zircons to infer maximum depositional ages of strata: A test against a Colorado Plateau Mesozoic database. Earth Planet. Sci. Lett., 288(1-2), 115-125.

92. Minoux, L. 1980. Stratigraphie, structure et métamorphisme de l'île d'Amorgos (Cyclades, Grèce). Ph.D. Thesis, University of Pierre et Marie Curie.

93. Dürr, S. 1985. Geological Map of Greece, 1:50.000, Amorgos-Donousa Sheet. Institute of Geological and Mining Research: Athens.

94. Laskou, M., and Economou, M. 1990. Platinum group element and gold concentrations in Greek bauxites. Geol. Balc., NICA, 21. 2, Sofia, p. 65-77.

95. Ring, U., and Layer, P.W. 2003. High-pressure metamorphism in the Aegean, eastern Mediterranean: underplating and exhumation from the Late Cretaceous until the Miocene to Recent above the retreating Hellenic subduction zone. Tectonics, 22 (3).

96. Tomaschek, F., Kennedy, A.K., Villa, I.M., Lagos, M., Ballhaus, C. 2003. Zircons from Syros, Cyclades, Greece - recrystallization and mobilization of zircon during high pressure metamorphism. J. Petrol., 44, 1977-2002.

97. Forster, M.A. and Lister, G.S. 2005. Several distinct tectono-metamorphic slices in the Cycladic eclogite-blueschist belt, Greece. Contr. Mineral. Petrol., 150(5), pp.523-545.

98. Putlitz, B., Cosca, M.A. and Schumacher, J.C. 2005. Prograde mica 40Ar/39Ar growth ages recorded in high pressure rocks (Syros, Cyclades, Greece). Chem. Geol., 214(1-2), pp.79-98.

99. Lister, G. S., \& Forster, M. A. 2016. White mica 40Ar/39Ar age spectra and the timing of multiple episodes of high-P metamorphic mineral growth in the Cycladic eclogite-blueschist belt, Syros, Aegean Sea, Greece. J. Metamorph. Geol., 34(5), 401-421.

100. Laurent, V., Lanari, P., Naïr, I., Augier, R., Lahfid, A., \& Jolivet, L. 2018. Exhumation of eclogite and blueschist (Cyclades, Greece): Pressure-temperature evolution determined by thermobarometry and garnet equilibrium modelling. J. Metamorph. Geol., 36(6), 769-798. https://doi.org/10.1111/jmg.12309.

101. van der Maar, P. A., \& Jansen, J. B. H. 1983. The geology of the polymetamorphic complex of Ios, Cyclades, Greece and its significance for the Cycladic Massif. Int. J. Earth Sci., 72(1), 283-299. https://doi.org/10.1007/BF01765910.

102. Baldwin, S. L. 1996. Contrasting PTt histories for blueschists from the western Baja Terrane and the Aegean: Effects of synsubduction exhumation and backarc extension. Washington DC Am. Geophys. Union, Geophys. Monogr. Ser., 96, pp.135-141.

103. Avigad, D. 1998. High-pressure metamorphism and cooling on SE Naxos (Cyclades, Greece). European J. Mineral., 10, $1309-1319$.

104. Jansen, J.B.H., Schuiling, R.D. 1976. Metamorphism on Naxos: petrology and geothermal gradients. Am. J. Sci., 276 (10), 12251253.

105. Buick, I.S., Holland, T.J.B. 1989. The P-T-t path associated with crustal extension, Naxos, Cyclades. In: Daly, J.S., Cliff, R.A., Yardley, B.W.D., (eds): The evolution of metamorphic belts. Geol. Soc. London Spec. Publ., 40, 365371. 
106. Duchene, S., Aissa, R., Vanderhaeghe, O. 2006. Pressure-temperature-time evolution of metamorphic rocks from Naxos (Cyclades, Greece): constraints from thermobarometry and Rb/Sr dating. Geodin. Acta, 19, 301-321.

107. Martin, L., Duchêne, S., Deloule, E. and Vanderhaeghe, O. 2006. The isotopic composition of zircon and garnet: A record of the metamorphic history of Naxos, Greece. Lithos, 87(3-4), pp.174-192.

108. Martin, L.A., Duchêne, S., Deloule, E. and Vanderhaeghe, O. 2008. Mobility of trace elements and oxygen in zircon during metamorphism: consequences for geochemical tracing. Earth Planet. Sci. Lett., 267(1-2), pp.161-174.

109. Laurent, V., Jolivet, L., Roche, V., Augier, R., Scaillet, S. and Cardello, G.L. 2016. Strain localization in a fossilized subduction channel: Insights from the Cycladic Blueschist Unit (Syros, Greece). Tectonophysics, 672, pp.150-169.

110. Vavassis, I., De Bono, A., Stampfli, G.M., Giorgis, D., Valloton, A., Amelin, Y. 2000. U-Pb and Ar-Ar geochronological data from Pelagonian basement in Evia (Greece): geodynamic implications for the evolution of the Paleotethys. Schw. Mineral. Petrograph. Mitteil., 80, 21-43.

111. Avigad, D., Gerdes, A., Morag, N., Bechstadt, T. 2012. Coupled U-Pb- Hf of detrital zircons of Cambrian sandstones from Morocco and Sardinia: implications for provenance and Precambrian crustal evolution of north Gondwana. Gondwana Res., 21, 690-703.

112. Meinhold, G., Morton, A.C., Avigad, D. 2013. New insights into peri-Gondwana paleogeography and the Gondwana super-fan system from detrital zircon U-Pb ages. Gondwana Res., 23, 661-665. doi:10.1016/j.gr.2012.05.003.

113. Xypolias, P., Dörr, W., Zulauf, G. 2006. Late Carboniferous plutonism within the pre-Alpine basement of the External Hellenides (Kithira, Greece): evidence from U-Pb zircon dating. J. Geol. Soc. London, 163, 539-547.

114. Kydonakis, K., Gallagher, K., Brun, J.P., Jolivet, M., Gueydan, F., Kostopoulos, D. 2014. Upper Cretaceous exhumation of the western Rhodope Metamorphic Province (Chalkidiki Peninsula, northern Greece). Tectonics, 33 (6), $1113-1132$. http://dx.doi.org/10.1002/2014TC003572.

115. Dörr, W., Zulauf, G., Gerdes, A., Lahaye, J., Kowalczyk, G. 2015. A hidden Tonian basement in the eastern Mediterranean: Age constraints from $\mathrm{U}-\mathrm{Pb}$ data of magmatic and detrital zircons of the External Hellenides (Crete and Peloponnesus). Precambrian Res., 258, 83-108.

116. Zulauf, G., Dörr, W., Fisher-Spurlock, S.C., Gerdes, A., Chatzaras, V., and Xypolias, P. 2015. Closure of the Paleo-Tethys in the External Hellenides: Constraints from U-Pb ages of magmatic and detrital zircons (Crete). Gondwana Res., 28(2), 642-667. http://dx.doi.org/10.1016/j.gr.2014.06.011.

117. Zulauf, G., Dörr, W., Marko L., and Krahl J. 2018. The late Eo-Cimmerian evolution of the external Hellenides: constraints from microfabrics and U-Pb detrital zircon ages of Upper Triassic (meta)sediments (Crete, Greece). Int. J. Earth Sci., 107(7), $2859-2894$. doi:10.1007/s00531-018-1632-8.

118. Ring, U., Laws, S., Bernet, M. 1999. Structural analysis of a complex nappe sequence and late-orogenic basins from the Aegean Island of Samos, Greece. J. Struct. Geol., 21, 1575-1601.

119. Tomaschek, F., Kennedy, A., Keay, S., Ballhaus, C. 2001. Geochronological constraints on Carboniferous and Triassic magmatism in the Cyclades: SHRIMP U-Pb ages of zircons from Syros, Greece. J. Confer. Abstr., 6, 315.

120. Reischmann, T., Kostopoulos, D.K., Loos, S., Anders, B., Avgerinas, A. and Sklavounos, S.A., 2001. Late Palaeozoic magmatism in the basement rocks southwest of Mt. Olympos, Central Pelagonian Zone, Greece: remnants of a Permo-Carboniferous magmatic arc. Bull. Geol. Soc. Greece, 34(3), pp.985-993.

121. Anders, B., Reischmann, T., Kostopoulos, D. 2007. Zircon geochronology of basement rocks from the Pelagonian Zone, Greece: constraints on the pre-Alpine evolution of the westernmost Internal Hellenides. Int. J. Earth Sci., 96, 639-661.

122. Robertson, A.H.F., Clift, P.D., Degnan, P.J., Jones, G. 1991. Palaeogeographic and palaeotectonic evolution of the Eastern Mediterranean Neotethys. Palaeogeogr. Palaeoclim. Palaeoecol., 87, 289-343. 
123. Robertson, A.H.F., Dixon, J.E., Brown, S., Collins, A., Morris, A., Pickett, E.A., Sharp, I., Ustaömer, T. 1996. Alternative tectonic models for the Late Palaeozoic-Early Tertiary development of Tethys in the Eastern Mediterranean region. In: Morris, A., Tarling, D.H. (eds) Palaeomagnetism and tectonics of the Mediterranean region. Geol. Soc. London, Spec. Publ., 105, $239-263$.

124. Stampfli, G.M., and Borel, G.D. 2002. A plate tectonic model for the Paleozoic and Mesozoic constrained by dynamic plate boundaries and restored synthetic oceanic isochrons. Earth Planet. Sci. Lett., 196(1-2), 17-33.

125. Robertson, A.H.F. 2006. Sedimentary evidence from the south Mediterranean region (Sicily, Crete, Peloponnese, Evia) used to test alternative models for the regional tectonic setting of Tethys during Late Palaeozoic-Early Mesozoic time. In: Robertson, A.H.F., Mountrakis, D. (eds) Tectonic development of the eastern Mediterranean region. Geol. Soc. London, Spec. Publ., 260, 91-154.

126. Buick, I.S. 1991. The late Alpine evolution of an extensional shear zone, Naxos, Greece. J. Geol. Soc., 148(1), 93-103.

127. Aubouin, J., Bonneau, M., \& Celet, P. 1970. Contribution à la géologie des Hellènides: le Gavrovo, le Pinde et la zone ophiolique subpélagonienne. Soc. Géol. Nord.

128. Fleury, J. J. 1980. Evolution d'une platforme et d'un bassin dans leur cadre alpin: les zones de Gavrovo-Tripolitza et du PindeOlonos. Soc. Géol. Nord, Spec. Publ., 4, 651.

129. Baldwin, S. L., \& Lister, G. S. 1998. Thermochronology of the South Cyclades Shear Zone, Ios, Greece: Effects of ductile shear in the argon partial retention zone. J. Geophys. Res., 103:7315-7336. doi:10.1029/97JB03106.

130. Vermeesch, P. 2018. IsoplotR: a free and open toolbox for geochronology. Geosci. Front., v.9, p.1479-1493. doi:10.1016/j.gsf.2018.04.001. 